\title{
Confirmatory Model to Measure Attitude towards Mathematics in Higher Education Students: Study Case in SLP Mexico
}

\author{
Milka Elena Escalera Chávez ${ }^{1}$, Elena Moreno García ${ }^{2 \star}$, Carlos Alberto Rojas Kramer ${ }^{2}$ \\ ${ }^{1}$ Unidad Académica Multidisciplinaria Zona Media, Universidad Autónoma de San Luis Potosí, MÉXICO \\ ${ }^{2}$ Researcher Professor at UCC Business School, Universidad Cristóbal Colón, Veracruz, MÉXICO \\ * CORRESPONDENCE: $\$ elenam@ucc.mx
}

\begin{abstract}
Despite the fact that mathematics is present and necessary in any area of daily life, students have little interest in developing mathematical skills. Hence, the aim of the study is to check whether the variables motivation, usefulness, anxiety, confidence, and liking are determining in their attitude towards mathematics. The present research is quantitative, not experimental, transversal and confirmatory. The sample was of 362 students belonging to the Multidisciplinary Academic Area Middle Zone, in the city of Rioverde, San Luis Potosí. The participating students are from the Administration (154), Public Accounting and Finance (112) and Marketing (96). The data was collected through the test designed by Auzmendi (1992) the Attitude towards Mathematics Scale (EAM), which consists of 25 items. The results indicate that although it is true that students show a positive attitude (liking), they also admit that it causes them anxiety because they do not feel confident in their mathematical ability. It is necessary to add that the student does not feel any stimulus to have an interest in the subject.
\end{abstract}

Keywords: attitude, anxiety, mathematics, students, Mexico

\section{INTRODUCTION}

Although the discipline of mathematics is present and necessary in any area of daily life, students have little interest in developing mathematical skills; this rejection towards mathematics is probably a direct consequence of the influence of variables of a cognitive and emotional nature.

Nowadays in Mexico, a high percentage of students of higher level show a lack of competence in mathematics, this according to the results of studies carried out in different institutions of the higher level by Peña (2002), Velázquez (2008), Sosa (2009) and Gómez (2009), García-Santillán et al (2017, 2018). As an important data, these works revealed that the students of the Universidad Nacional Autónoma de México (UNAM) are not competent in mathematics, because at least $40.5 \%$ are not trained in this discipline.

On the other hand, in a study conducted by Sosa (2009), he found that $90 \%$ of the students of the Accounting and Administration degree of the UASLP lack basic knowledge of mathematics. Another data is revealed by Gómez (2009), who showed that a large percentage of students of mathematics at the Universidad Veracruzana, Campus Coatzacoalcos, have considerable deficiencies.

In the same idea, Gonzalez (2000) shows that students attitude is a factor that determines the willingness to learn, which influences their behavior. In this regard, Colorado, Juarez and Hernandez (2011) conceive the attitude towards mathematics as a cluster of capabilities that people externalize to admit or not, certain capabilities. The attitudinal factor can be determined by circumstances, episodes or critical incidents for the

Article History: Received 23 September $2018 \bullet$ Revised 16 November $2018 \bullet$ Accepted 23 November 2018

(C) 2019 by the authors; licensee Modestum Ltd., UK. Open Access terms of the Creative Commons Attribution 4.0 International License (http://creativecommons.org/licenses/by/4.0/) apply. The license permits unrestricted use, distribution, and reproduction in any medium, on the condition that users give exact credit to the original author(s) and the source, provide a link to the Creative Commons license, and indicate if they made any changes. 
configuration of a trial, in his words they state that: "the attitude reflects the perceptions of people with respect to their environment; which is of great interest for different approaches".

Students' attitude towards mathematics has become an alarming issue in higher education institutions in the country. We must consider that mathematics is a basic quantitative discipline for the personal and academic development of every individual; therefore, the use of them is crucial throughout people's life because they are and will always be necessary, no matter the stage of life in which the student is or for what purpose he uses them.

In this sense, Auzmendi (1992) designed a scale to measure the student's attitude towards mathematics, composed by 25 items integrated into five dimensions (usefulness, anxiety, motivation, liking and confidence). This scale allows measuring the attitude toward mathematics.

The Auzmendi Scale was used in several studies with significant results. This has allowed explaining the anxiety towards mathematics in different populations of students (Gómez, 2009; Peña, 2002; Sosa, 2009; Velázquez, 2008). Therefore, there is interest in studying the phenomenon of attitude in the students who attend the university courses in Administration, Public Accounting and Marketing of the Multidisciplinary Academic Area at UASLP's Media Zone.

To carry out the study, it established the following question: How do students perceive the motivation, usefulness, liking, anxiety and confidence as determinants variables of attitude towards mathematics? Therefore, the aim of the study is to check whether the variables motivation, usefulness, liking, anxiety and confidence are determining factors in their attitude towards mathematics.

This research is important for the institution since by using the information obtained, it can update its teaching-learning process to achieve significant learning in the students. Hence, this work will also provide empirical evidence that allows mathematics teachers to identify the attitudes that prevent the student from tackling the mathematics subjects, in order to generate didactic strategies aimed at achieving a better willingness from students towards the discipline, therefore, better academic achievement.

In addition, as students improve the teaching-learning processes oriented in the factors that contribute to the attitude, they will be able to develop their competences better that will result in their academic practice, as well as in their professional life. Nowadays, the organisms in charge of designing the Educational policies are focused on the transmission of skills to young people so that they develop their potential and can participate in solving problems in their workplace.

\section{LITERATURE REVIEW}

Petriz, Ríos, López, and Quiroz (2010), studied the attitudes of undergraduate students in Administration who were in the second and fourth semesters of a state university. Their results show that students with a higher degree of motivation toward mathematics achieved a higher level of performance. Similarly, the relationship between liking and performance show a significant correlation, also in terms of anxiety; it suggests that a small dose in students leads to a higher performance in mathematics.

On the other hand, Estrada and Díez (2011) report that liking mathematics has nothing to do with the person's age, likewise the relation between the level of studies reached and the feeling towards mathematics. In addition, there is a clear relationship between the emotional and cognitive dimensions in the learning of mathematics. Similarly, we compare the attitude towards mathematics of students of the Bachelor Degrees in Sciences and Statistical Techniques, Economics, Computing, Accounting and Administration.

In general, all students show a good attitude toward mathematics. The applicability in the observed sample is the most important construct and the one with fewer loads is the skill and anxiety. The degrees in Economics and Statistics are the ones that show the best attitude towards mathematics with respect to the four indicators used, followed in descending order of accounting and information technology, and finally administration.

In the same way, Cardoso, Cerecedo and Ramos (2012), when evaluating the attitude of the postgraduate students in administration towards the mathematics subject, found that the students perceive it as a useful but difficult discipline, in addition they manifested an attitude of distrust and anxiety in the situations that involve its use. They also found that men and women who start the graduate program in administration differ in their level of anxiety when doing activities related to mathematics.

Similarly, the authors mention that the anxiety towards mathematics is the behavior of a student that manifests itself by an excessive fear to commit errors, diminishing the attention span and therefore to a 


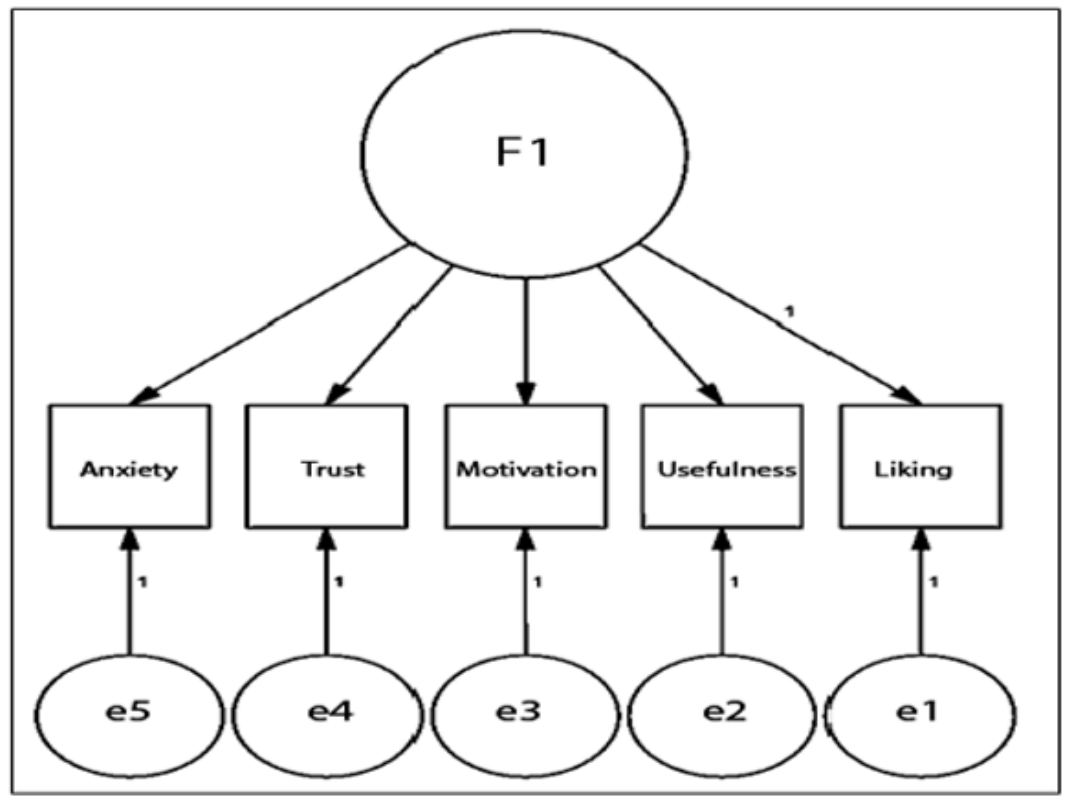

Figure 1. Auzmendi Model

deficient reasoning; the motivation is the behavior of a person directed towards a preferential activity. About the enjoyment of mathematics, it is described as the extension to which a student feels happy in relation to the study of mathematics (Schofield, 2010).

While trust refers to the security or to the hope that people have of an object or them self toward some situation, then the usefulness is the value that people give to an object, for example, the value that students gives to mathematics. In this idea, Dörfer, Duque and Soledad (2016) applied and validated the reliability of the scale of attitudes towards mathematics EAM, elaborated by Auzmendi (1992) and affirm that the factors anxiety, like, usefulness, motivation and confidence, explain $64.29 \%$ of the total variance of the data, so they conclude that the instrument is viable to measure the attitude towards mathematics.

\section{METHOD}

It is a non-experimental design because we do not manipulate the variables. In addition, it is a crosssectional type and confirmatory since we try to describe the attitude towards mathematics of higher-level students who attend the school year (2017-2018). It is confirmatory because the number of factors and pattern of relationships between the indicator and the factorial loads as well as other parameters, are specified. The pre-specified solution factor is evaluated in terms of how well it reproduces the variance and covariance matrix of the sample in the measured variables.

For purposes of the study, the sample is non-probabilistic since the samples are not representative by type of selection; are informal or arbitrary and, are based on general assumptions about the distribution of the variables in the population (Pimienta, 2000). The selected sample consisted of 362 students belonging to the Multidisciplinary Academic Area Middle Zone, in the city of Rioverde, San Luis Potosí. The sample comprises students of the profile: Administration (154), Public Accounting and Finance (112) and Marketing (96). In order to obtain the data, the test Attitude towards Mathematics Scale (EAM) designed by Auzmendi (1992), which consists of 25 items and classified into five dimensions: anxiety, liking, usefulness, motivation, and trust, was used (Figure 1).

Table 1 shows the description of each of the variables that make up the theoretical model proposed. 
Table 1. Variables, dimensions and indicators

\begin{tabular}{|c|c|c|}
\hline Variable & Dimension & Indicator \\
\hline \multirow{5}{*}{$\begin{array}{l}\text { Attitudes towards } \\
\text { mathematics } \\
\text { It is a list of affirmations } \\
\text { that express positive or } \\
\text { negative feelings and / or } \\
\text { beliefs about mathematics } \\
\text { (Aien, 1988). }\end{array}$} & Anxiety & Items \\
\hline & $\begin{array}{l}\text { Refers to the feeling of anxiety, fear that the student } \\
\text { manifests before the subject of mathematics }\end{array}$ & $2,3,7,8,12,13,17,18,22$ \\
\hline & Liking & \\
\hline & $\begin{array}{l}\text { It refers to the pleasure or enjoyment that causes the } \\
\text { mathematical work. }\end{array}$ & $4,9,14,24$ \\
\hline & Usefulness & \\
\hline \multirow{3}{*}{$\begin{array}{l}\text { According Auzmendi it is an } \\
\text { attitude that is related to } \\
\text { five different factors which } \\
\text { are: anxiety, like, } \\
\text { usefulness, motivation and } \\
\text { confidence in mathematics }\end{array}$} & $\begin{array}{l}\text { The value that the student gives to mathematics, to } \\
\text { the utility that he perceives that this subject can } \\
\text { have for his future profession. }\end{array}$ & $1,6,1516,19$ and 21 \\
\hline & $\begin{array}{l}\text { Motivation } \\
\text { Reason that drives the student towards the study and } \\
\text { use of mathematics }\end{array}$ & $5,10,25$ \\
\hline & $\begin{array}{l}\text { Trust } \\
\text { Confidence that causes skill in mathematics }\end{array}$ & $11,20,23$ \\
\hline
\end{tabular}

Source: Auzmendi (1992)

Table 2. Measures Goodness of Fit

\begin{tabular}{ll}
\hline Indicators & Value \\
\hline Chi-square X2 & 4.578 \\
\hline Significance level & 0.916 \\
\hline Goodness of Fit Index (GFI) & 0.995 \\
\hline Adjusted Goodness of Fit Index (AGFI) & 0.985 \\
\hline Root Mean Square Error of Approximation (RMSEA) & 0.000 \\
\hline
\end{tabular}

Source: own

To determine the contribution of each factor in the attitude towards mathematics a structural analysis was used. The evaluation of the multivariate normality of the set of factors is of 4.815, a parameter that is within the permissible limits according to Byrne (2001) that indicates a multivariate normality of less than 5.0.

\section{RESULTS}

Table 2 shows the measures of goodness of fit of the model. The Chi square value (4.578 with 5 degrees of freedom) has a level of significance of .916 above the minimum level of 0.05 (Hair, et al., 1999), this indicates a good fit of the model. Also the value of GFI has a value of .995 quite acceptable since the recommended value is (0.90), parsimony index of GFI has a value of 0.985 greater than the recommended (0.90), finally the Medium Square Residue shows a value of 0.00 which is less than 0.5 (Hair, et al., 1999).

Of the five factors proposed by Auzmendi to determine the student attitude towards mathematics, the factor that gives more weight to the students (of the Bachelor of Administration, Public Accounting and Bachelor of Marketing degrees) is anxiety (0.68) this is, the student shows fear before the subject of mathematics, even if he likes it (0.61), however he does not see the usefulness in his future life (0.23), nor finds a reason for studying it and therefore does not feel confident in this discipline (Figure 2). 


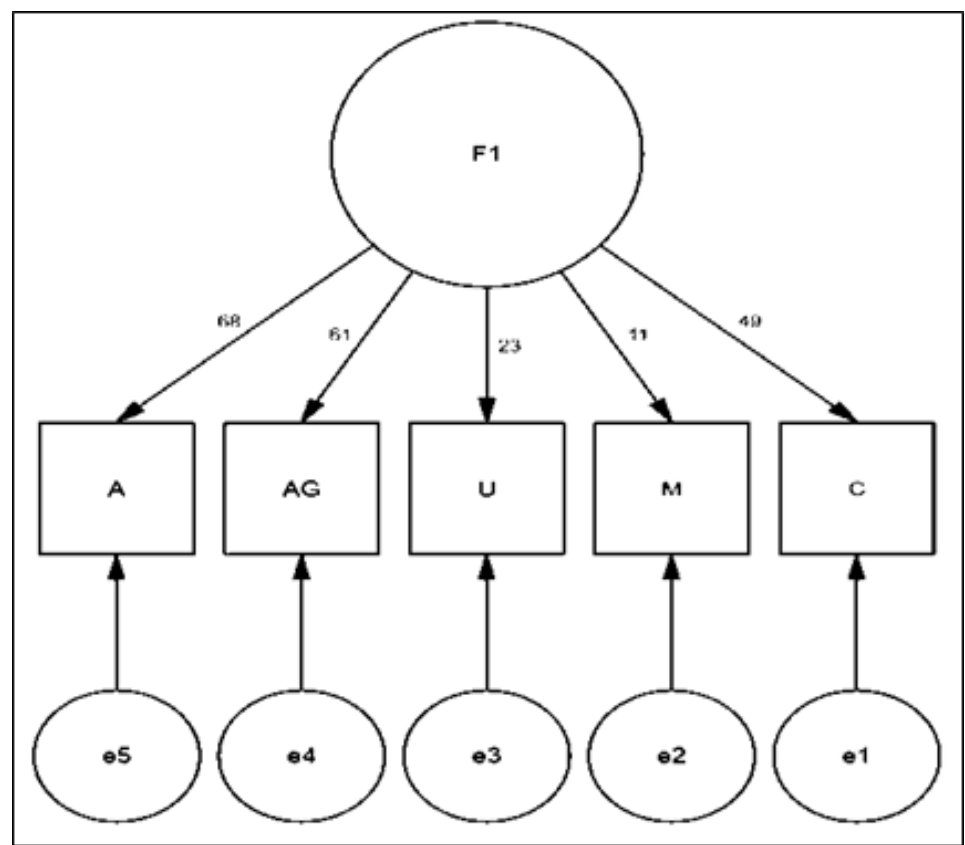

Figure 2. Auzmendi model with factorial weights

\section{FINAL REMARKS}

The objective of this research was achieved as it was found that the variables motivation, usefulness, anxiety, confidence and liking are determining in their attitude towards mathematics, although it is true that they show a positive attitude (liking), they also admit that it causes anxiety since they do not feel confident of their mathematical ability, it must also be added that the student does not feel any encouragement to have an interest in the subject.

The results coincide with those of Cardoso, Cerecedo and Ramos (2012), which show that students perceive mathematics as a useful but difficult discipline, and they showed an attitude of distrust and anxiety in situations that involve their use. In this regard, this research shows evidence that supports authors such as Dörfer, Duque and Soledad (2016) provide on the scale of attitudes towards mathematics EAM, developed by Auzmendi (1992) and claim that the factors anxiety, like, utility, motivation and confidence are viable to measure attitude towards mathematics.

\section{Disclosure statement}

No potential conflict of interest was reported by the authors.

\section{Notes on contributors}

Milka Elena Escalera Chávez - Unidad Académica Multidisciplinaria Zona Media, Universidad Autónoma de San Luis Potosí, México.

Elena Moreno García - Researcher Professor at UCC Business School, Universidad Cristóbal Colón, Veracruz, México.

Carlos Alberto Rojas Kramer - Researcher Professor at UCC Business School, Universidad Cristóbal Colón, Veracruz, México.

\section{REFERENCES}

Auzmendi, E. (1992). Las actitudes hacia la matemática-estadística en las enseñanzas media y universitaria. Bilbao: Mensajero.

Byrne, B (2009). Structural Equation Modeling With AMOS: Basic Concepts, Applications, and Programming. USA: Routledge Academic; Edición. 
Colorado. J., Juárez, S., \& Hernández, ML. (2011). Actitud hacia la matemática en estudiantes del área económica administrativa. In XV Congreso Internacional de Investigación en Ciencias Administrativas, mayo. Veracruz, México.

De la Peña, J. (2002). Algunos problemas de la educación en matemáticas en México. México: Siglo XXI Drexel University.

Dörfer, C., Duque, U., \& Soledad, G. (2016). Medición de la actitud hacia las matemáticas en estudiantes de licenciatura en administración: un estudio piloto. Vincula Tégica. EFA, 2(1), 1329-1348.

Estrada, A., \& Diez, J. (2011). Las actitudes hacia las Matemáticas. Análisis descriptivo de un estudio de caso exploratorio centrado en la Educación Matemática de familiares. Revista de Investigación en Educación, 9(2), 116-132.

García-Santillán, A., García-Cabrera, R.V., Molchanova, V.S., García-Cabrera, V. (2018). Psychometric properties of the Scale of Mato and Muñoz-Vázquez in medical undergraduate students sample. European Journal of Contemporary Education, 7(2), 332-343. https://doi.org/10.13187/ejced.2018.2.332

García-Santillán, A., Ochoa-Domínguez, T. E., \& Ramos-Hernández, J. J. (2018). Anxiety towards Mathematics of Workers in the Production Area of a Sugar Mill in Veracruz, Mexico. International Electronic Journal of Mathematics Education, 13(3), 207-219. https://oi.org/10.12973/iejme/3879

Gómez, J. (2009). Conocimientos previos de los alumnos de nuevo ingreso a la Facultad de Contaduría y Administración campus Coatzacoalcos. In XII Congreso Internacional sobre Innovaciones en Docencia e Investigación en Ciencias Económico Administrativas, octubre. Querétaro, México.

Hair, J. F., Anderson, R. E., \& Thatham, R.L. (1999). Análisis multivariante de datos (5th ed.). Madrid: Pearson Prentice Hall.

Petriz, A., Ríos, B, López C. Rosa María, \& Quiroz J. (2010). Niveles de desempeño y actitudes hacia las matemáticas en estudiantes de la Licenciatura en Administración en una universidad estatal mexicana. Revista mexicana de investigación educativa, 15(47), 1223-1249.

Schofield, H. (May-Jun, 1982). Sex, Grade Level, and the Relationship between Mathematics Attitude and Achievement in Children [Sexo, nivel, grado y relación entre la actitud matemática y logro en los niños]. The Journal of Educational Research 75(5), 280-284. https://doi.org/10.1080/00220671.1982.10885395

Sosa, E. (2009). La resolución de problemas y el uso de software en la enseñanza de las matemáticas. In XII Congreso Internacional sobre Innovaciones en Docencia e Investigación en Ciencias Económico Administrativas, octubre. Querétaro, México.

Velázquez, F. (2008). Opinión de los alumnos que asistieron al curso nivelatorio de matemáticas y su resultado en la materia de matemáticas básicas en la Facultad de Contaduría y Administración de la Universidad Autónoma Chihuahua. In XI Congreso Internacional sobre Innovaciones en Docencia e Investigación en Ciencias Económico Administrativas, septiembre. Guanajuato, México. 